Ann. Biol. anim. Bioch. Biophys., 1979, 19 (5), 1409-1417

\title{
Patterns of gene activity during ovum formation in the mouse
}

\author{
par G. P. M. MOORE, SUe LINTERN-MOORE* \\ C. S. I. R. O., Division of Animal Production, \\ P.O. Box 239, Blackfown, N.S.W. 2148, Australia. \\ * School of Biological Sciences, Macquarie University, \\ North Ryde, N.SW. 2113, Australia.
}

Summary. We have examined the transcriptional activities of the mouse oocyte genome during follicle growth in order to obtain information on the stages at which the synthesis of particular RNA species becomes important. The effects of gonadotrophins on these patterns of transcription have also been investigated. RNA synthesis in oocytes was measured at different stages of growth using a cytochemical application of the standard biochemical assay for DNA-dependent RNA polymerase. The presence of endogenous nucleolar and nucleoplasmic polymerases was detected by autoradiography and their relative activities were quantitated by grain counts. Both activities were relatively low in oocytes of the resting pool of small follicles but increased as growth commenced, reaching a peak as the oocytes approached maximum size. Thereafter RNA polymerase activities declined rapidly and were very low in the oocytes of large, antral follicles. Administration of PMSG to mice had no significant effect on the polymerases of oocytes of small follicles or during the early stages of follicles growth when compared with saline-treated controls. However, in oocytes which had attained maximum size, a statistically significant increase in nucleolar labelling was detected after PMSG treatment. The elevated levels of RNA polymerase activity were confined to oocytes within this growth compartment. These observations are discussed in relation to the way the production of gene transcripts is regulated during the growth of the oocyte, both with respect to the storage of informational molecules and the development of meiotic maturation competence.

\section{Introduction.}

The oocytes of the mammalian ovary exhibit a number of unusual developmental features. During an early phase of growth the oocyte becomes arrested in meiotic prophase and enters a resting stage. The quiescent period is of variable duration and appears to be related, at least in part, to the rate at which somatic cells accumulate in the surrounding follicular envelope. Upon receiving an appropriate stimulus, the oocyte commences a prolonged phase of growth towards ovulation. Successful development to a preovulatory state culminates in maturational changes which are accompanied by a resumption of meiosis.

The mechanisms which regulate these developmental events are yet to be defined. In an earlier paper of this Workshop we described some of the early functional and 
morphological changes which occur in oocytes of the resting pool during passage from a quiescent to an actively growing state. Here, the observations encompass the oocyte during its growth to maturity. Numerous recent studies have established a close relationship between the regulation of RNA synthesis and its metabolism and the growth of cells in culture. In the oocyte, the RNA's synthesized appear to have two basic functions : firstly to direct growth and maturation and secondly to provide a store of developmental information to be used after fertilization for the promotion of cleavage development. Certainly the oocyte at ovulation contains a relatively large amount, about 600 picograms, of RNA (Olds, Stern and Biggers, 1973). In the present paper we describe the patterns of gene activity which give rise to these RNA's in the oocyte and offer our interpretation of their significance during development.

The RNA synthesizing activity of the oocyte genome was measured directly by assay of ovary sections for the endogenous transcription enzymes, the DNA-dependent RNA polymerases. The RNA polymerases occur in a number of different forms in eukaryotic cells and some have been implicated in the synthesis of specific types of RNAs. Form I polymerases are located predominantly in the nucleolus and are involved in the synthesis of ribosomal RNA (rRNA). Form II polymerases occur in the nucleoplasm and catalyse the synthesis of heterogeneous nuclear $(\mathrm{Hn}) \mathrm{RNA}$, the presumed precursor of messenger (m) RNA (Roeder and Rutter, 1970 ; Zylber and Penman, 1971). The relative activities of these enzymes were measured in oocytes during growth in order to determine the periods over which the synthesis of particular gene products are important. Forms I and II polymerases were distinguished at each stage of oocyte growth by their localization within the nucleus and by their different sensitivities to the toxin, $\alpha$-amanitin (Moore and Ringertz, 1973 ; Moore, 1978).

\section{Materials and methods.}

Thirty day old mice of the Quackenbush strain were used in this study. The ovaries of 12 animals were removed, mounted in OCT compound (Miles Laboratories) and sectioned at $8 \mu \mathrm{m}$ on a cryostat. The sections were placed on gelatinized slides and fixed for $5 \mathrm{~min}$ in ethanol and acetone (1:1 by vol.). The preparations were dried and stored in a desiccator at $-15^{\circ} \mathrm{C}$.

To test the effects of gonadotrophins on the ovary, 4 females were injected daily with 100 IU pregnant mare serum gonadotrophin (PMSG) in saline over three days. Littermate control animals were injected with saline alone. On the fourth day the ovaries were removed and sectioned as described above.

Sectioned ovaries were assayed for endogenous RNA polymerase activity using published methods (Moore and Ringertz, 1973 ; Moore, 1978). The complete reaction mixture contained, in $0.5 \mathrm{ml}: 50 \mu$ moles Tris-HCl buffer $(\mathrm{pH} 7.9) ; 6 \mu$ moles 2-mercaptoethanol ; $75 \mu$ moles sucrose ; 300 nmoles each of ATP, GTP and CTP (Sigma Chemical Co.) ; 10 nmoles of ${ }^{3} \mathrm{H}$-UTP (13 Ci/mmol, Radiochemical Centre) ; $4 \mu$ moles $\mathrm{MgCl}_{2}$; $1 \mu$ mole $\mathrm{MnCl}_{2}$ and $0.04 \mathrm{M}$ ammonium sulphate.

Preparations were incubated with the assay solutions for $30 \mathrm{~min}$ at $37^{\circ} \mathrm{C}$. Subsequently, the sections were fixed, extracted with 5 p. 100 trichloracetic acid (TCA) and prepared for autoradiography. Slides were coated with liquid emulsion and 
exposed in light tight boxes for two days. The autoradiographs were then developed and stained with haematoxylin and eosin.

Examination of autoradiographs showed that radioactivity was predominantly localized within the nuclei of ovarian cells. The label was not removed by cold TCA, but control incubations in the presence of actinomycin $D$ and ribonuclease resulted in very low radioactive incorporation, indicating that the reaction was dependent on DNA and that RNA, incorporating ${ }^{3} \mathrm{H}-U M P$, was produced (Moore and LinternMoore, 1978).

The features of the reaction are characteristic of the endogenous transcription enzymes, the RNA polymerases (Moore, 1978), The polymerases which are active are involved solely in the elongation of RNA chains which were initiated in vivo. No new chains are initiated during incubation with the assay medium. Thus, the amount of label incorporated by the oocyte is a function of the number of polymerase molecules which were active at the time of fixation.

The ovary sections were scanned for oocytes in which the plane of the section passed through the oocyte nucleolus. The numbers of silver grains over the nucleolus and nucleoplasm were counted. The growth stage of the follicle was determined using the classification of Pedersen and Peters (1968). The number of background grains was counted in each slide and subtracted from the nucleolar and nucleoplasmic counts using the method described elsewhere (Moore and Lintern-Moore, 1978).

\section{Results.}

Radioactivity was observed in oocyte nuclei at all stages of follicular growth (table 1). Incorporation due to nucleolar and nucleoplasmic polymerases was detected in small oocytes of the resting pool (type 2 follicles). Both enzyme activities increased in follicles which had begun to grow (type $3 a$ ) and continued to increase thereafter, reaching a peak in multilaminar follicles in which the oocytes were approaching maximum size (types 4 and $5 a$ ). Subsequent follicular development was accompanied by a

TABLE 1

Incorporation of ${ }^{3} \mathrm{H}-\mathrm{UMP}$ by mouse oocytes during growth

\begin{tabular}{|c|c|c|c|c|c|c|}
\hline \multirow{3}{*}{$\begin{array}{l}\text { Follicle } \\
\text { type }\end{array}$} & \multicolumn{3}{|c|}{ Complete assay solution } & \multicolumn{3}{|c|}{$\begin{array}{c}\text { Assay solution } \\
+\alpha \text {-amanitin }(5 \mu \mathrm{g} / \mathrm{ml})\end{array}$} \\
\hline & \multirow{2}{*}{$\begin{array}{l}\text { No. ooc. } \\
\text { counted }\end{array}$} & \multicolumn{2}{|c|}{ Grain no. $\pm S E M$} & \multirow{2}{*}{$\begin{array}{l}\text { No. ooc } \\
\text { counted }\end{array}$} & \multicolumn{2}{|c|}{ Grain no. $\pm S E M$} \\
\hline & & $\begin{array}{l}\text { Nucleo- } \\
\text { plasm }\end{array}$ & Nucleolus & & $\begin{array}{l}\text { Nucleo- } \\
\text { plasm }\end{array}$ & Nucleolus \\
\hline $\begin{array}{c}2 \\
3 a \\
3 b \\
4 \\
5 a \\
5 b \\
6 \text { and } 7\end{array}$ & $\begin{array}{r}43 \\
49 \\
48 \\
18 \\
19 \\
6 \\
9\end{array}$ & $\begin{array}{r}9.4 \pm 0.8 \\
16.3 \pm 1.0 \\
29.6 \pm 1.7 \\
47.3 \pm 3.7 \\
58.3 \pm 3.6 \\
20.0 \pm 5.2 \\
5.2 \pm 1.5\end{array}$ & $\begin{array}{r}12.3 \pm 1.3 \\
19.4 \pm 1.4 \\
29.1 \pm 1.9 \\
34.9 \pm 3.1 \\
33.0 \pm 3.1 \\
11.8 \pm 3.1 \\
4.6 \pm 1.4\end{array}$ & $\begin{array}{r}36 \\
41 \\
52 \\
20 \\
25 \\
7 \\
13\end{array}$ & $\begin{array}{r}2.8 \pm 0.5 \\
5.8 \pm 0.9 \\
6.4 \pm 0.9 \\
8.2 \pm 1.5 \\
10.2 \pm 1.7 \\
8.3 \pm 3.7 \\
0.9 \pm 2.8\end{array}$ & $\begin{array}{r}14.3 \pm 1.3 \\
23.6 \pm 1.9 \\
40.3 \pm 1.9 \\
44.2 \pm 5.0 \\
51.2 \pm 2.3 \\
25.3 \pm 5.2 \\
3.3 \pm 1.5\end{array}$ \\
\hline
\end{tabular}


marked decline in nucleolar and nucleoplasmic activies (type $5 b$ follicles) falling to relatively low levels in the oocytes of large follicles (types 6 and 7).

Ovary sections were also assayed in the presence of $\alpha$-amanitin, a toxin known to selectively inhibit the activity of form II polymerase. This caused a marked reduction in the amount of radioactivity in the oocyte nucleoplasm (table 1). However, nucleolar labelling was unaffected, indicating that form I polymerases which are resistant to $\alpha$-amanitin were active. The levels of nucleolar polymerase activity of oocytes assayed in the presence of $\alpha$-amanitin were very similar to those found in its absence (table 1 ). Radioactive incorporation increased during oocyte growth, reaching a peak in multilaminar type $5 a$ follicles. Thereafter, polymerase activity declined to relatively low levels in the oocytes of antral follicles. Some nucleoplasmic incorporation persisted in the presence of $\alpha$-amanitin suggesting the existence of a distinct extranucleolar enzyme which was resistant to the toxin.

Administration of PMSG to experimental animals had no significant effect on nucleolar and nucleoplasmic RNA polymerase activities in oocytes of small follicles or during the early stages of follicle growth when compared with saline-treated controls (figs. $1 a$ and $b$ ). However, in oocytes approaching maximum size and in which RNA polymerases were most active (type $5 a$ follicles), a statistically significant increase in nucleolar label was detected after PMSG treatment $\left(t_{11}=2.76, p<0.05\right)$. The

INCORPORATION OF 3 H-UMP INTO OOCYIE NUCLEOLUS AFTER SALINE $\square$ OR PMSG aDMINISTHATION

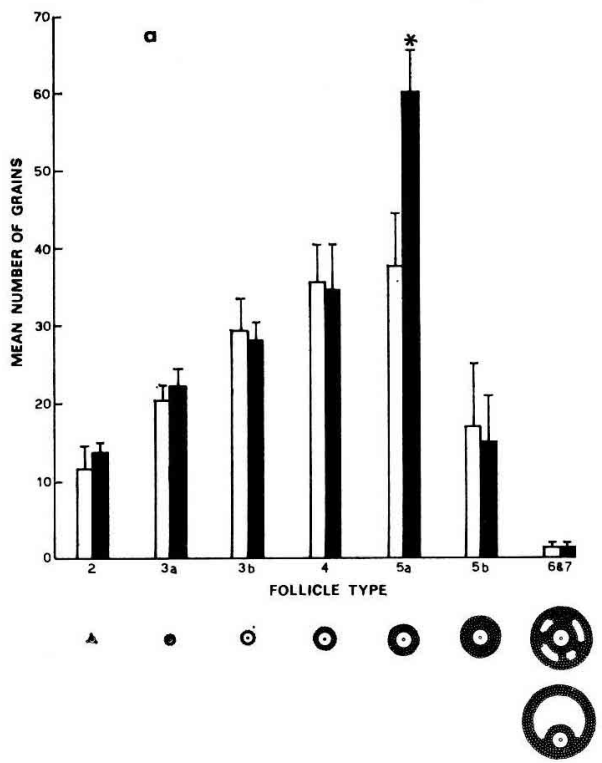

INCORPORATION OF 3H-UMP INTO OOCYTE NUCLEOPLASM AFter SALINE $\square$ OR PMSG aDMINISTRATION

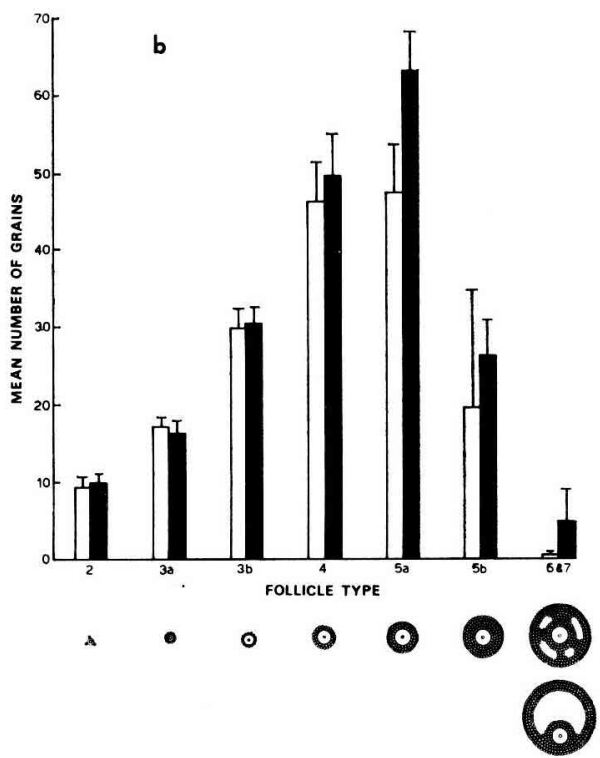

FIG. $1 a$ and 1 b. - Incorporation of ${ }^{3} \mathrm{H}-$ UMP by the nucleolus $(1 a)$ and nucleoplasm (1b) of mouse oocyfes. Open bars : numbers of silver grains over oocytes of animals treated with saline; closed bars : numbers of silver grains over oocytes of animals treated with PMSG. Stages of follicle development are defined according to the classification of Pedersen and Peters (1968), reproduced by permission of Dr. H. Peters and J. Reprod. Fert. 
elevated levels of RNA polymerase activity were confined to oocytes within the type $5 a$ compartment ; there were no statistical differences between experimental and control values at subsequent stages of follicle development (types $5 b, 6$ and 7 ). The localization of increased activity within the nucleolus suggested that predominantly form I RNA polymerases were responding. This was investigated further by treating mice with PMSG or saline followed by assay of sectioned ovaries for the transcription enzymes in the presence of $\alpha$-amanitin. Autoradiography revealed as before (see table 1 ), that nucleolar labelling was not affected, whereas there was a marked reduction in label in the nucleoplasmic compartment (figs $2 a$ and $b$ ). Grain counts confirmed the observation of figure $1 a$. There was a statistically significant increase in label incorporation by the nucleoli of oocytes of type $5 a$ follicles in ovaries from PMSG-treated animals when compared with saline-treated controls $\left(t_{21}=2.75, p<0.05\right)$. At all other stages of follicular development, nucleolar grain numbers were not statistically different from control values.

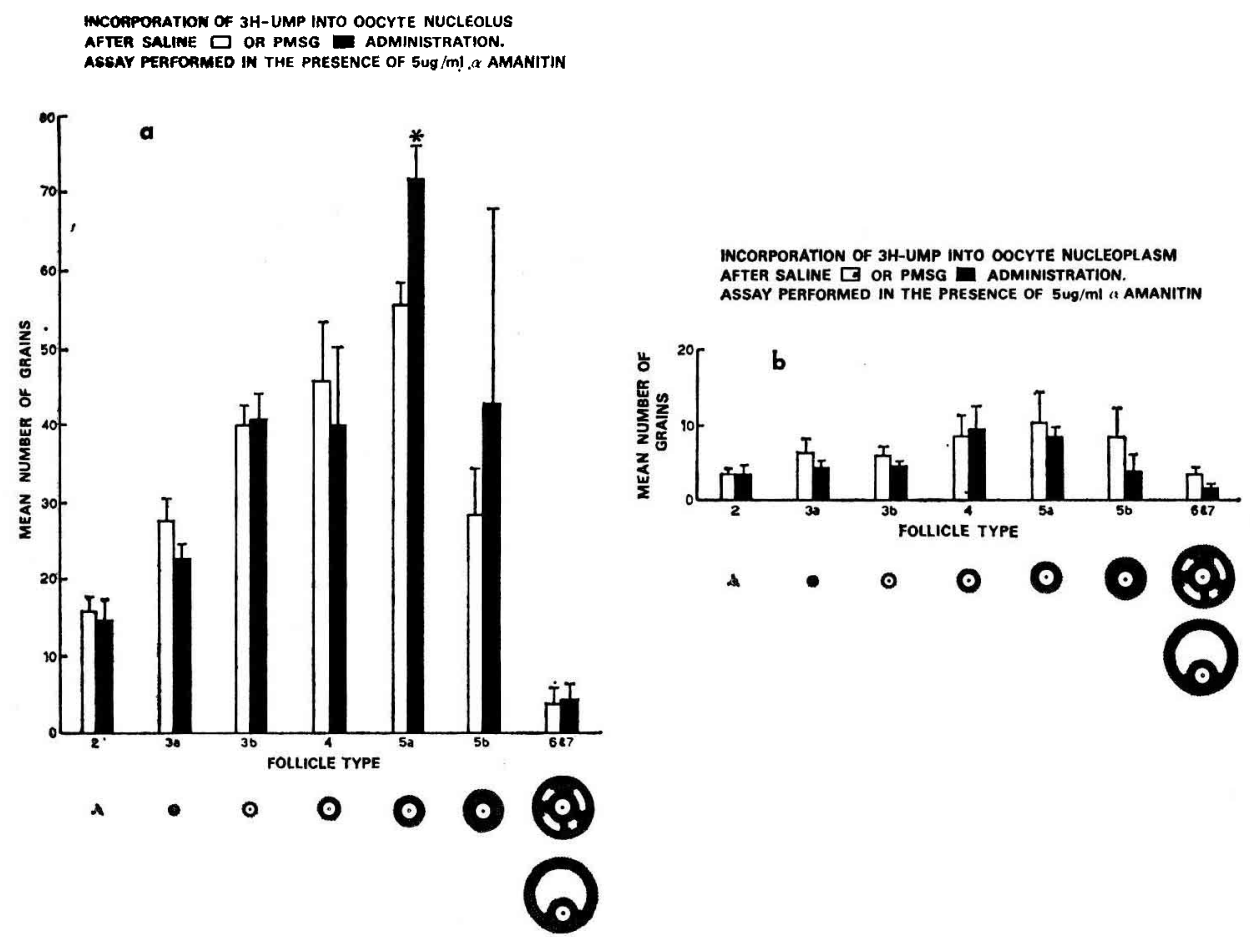

FIG. $2 a$ and $2 b$. - Incorporation of ${ }^{3} \mathrm{H}$-UMP by mouse oocyfes assayed in the presence of $5 \mu \mathrm{g} / \mathrm{ml} \alpha$-amanitin. Label incorporation into nucleolus $(2 a)$ is unaffected whereas in the nucleoplasm (2b) labelling is reduced. Results for saline- and PMSG-treated animals are expressed as in figure 1.

\section{Discussion.}

Studies of cultured cell lines have revealed that there are a number of different systems controlling the synthesis and metabolism of major RNA species during growth. The resultant effect of these regulatory mechanisms is to cause the rRNA, mRNA and 
transfer RNA (†RNA) contents of growing cells to increase over those of the resting state (Johnson ef al., 1974). Clearly, the enzymes which catalyze the synthesis of these RNA's must play a significant role in the regulation of cell growth. Thus, the extensive changes in polymerase I and II activities observed here should provide some insights into the way RNA is produced for the growth of the oocyte and the storage of developmental information.

A progressive increase in basophilia has been observed in the mouse oocyle during growth. This appears to be correlated with increases in the RNA content of the cytoplasm (Flax, 1953 ; Moore, unpublished observations). Most of the RNA present in the oocyte cytoplasm at ovulation is ribosomal in nature (Bachvarova, 1974). In model systems, the rate of rRNA formation, which is controlled by RNA polymerase I, is closely associated with the growth state of the cell (Johnson ef al., 1977). The changes in nucleolar activity in the oocyte shown in table 1 are consistent with this proposal. The data also indicate that stored rRNA would be transcribed during the phase of oocyte growth. Additional evidence for the mouse has been provided by the work of Oakberg (1968), Moore ef al. (1974) and Jahn ef al. (1976). The synthesis and conservation of $r R N A$, sometimes after considerable amplification of the rDNA genes, is a notable feature of oocyte growth in both vertebrate and invertebrate species.

The form II polymerases of the growing mouse oocyte appears to be relatively more active than the form I polymerases. Cultured cells accumulate mRNA faster than rRNA during growth (Johnson ef al., 1974) although differences in the stabilities of these two species are also significant (Johnson et al., 1976). Certainly, much of the RNA produced must be turned over during development, since only a relatively small fraction in the ovulated oocyte is of a heterogeneous type (Bachvarova, 1974 ; Jahn et al., 1976).

The existence of an additional nucleoplasmic enzyme which is resistant to $\alpha$-amanitin is indicated by figure $2 b$. A polymerase with these features has been described by Weinmann and Roeder (1974) and designated a form III enzyme. This polymerase is thought to be involved in the synthesis of tRNA and the $5 \mathrm{~S}$ component of cytoplasmic ribosomes. Bachvarova (1974) and Jahn ef al. (1976) have reported that these low molecular weight species are present in ovulated mouse oocytes. All of these observations, together with the data presented here, suggest that the accumulation of the major RNA species in the cytoplasm of the oocyte is co-ordinated with changes in RNA polymerase I, II and possibly III activities during growth.

We have also observed an effect of PMSG on the germ cells of the mouse ovary. Our results show that RNA polymerase activity is enhanced after gonadotrophin treatment, specifically in the oocytes of multilaminar, type $5 a$ follicles. The mechanism by which this stimulation occurred was not determined. The observed increase in transcription may be an indirect response mediated through the surrounding cells, although this does not appear to be primarily related to a change in oestrogen production (Moore and Lintern-Moore, 1979). Furthermore, no significant variations in RNA polymerase activity were observed in granulosa cell nuclei of type $5 a$ follicles after treatment with PMSG (unpublished observations).

The specific activation of nucleolar, $\alpha$-amanitin-resistant polymerases in the oocyte after PMSG indicates an involvement of form I enzymes and consequently, the transcription of rDNA genes is increased. This response has been commonly observed in 
target cells after hormone administration. An increase in mRNA synthesis also occurs, although to a much less marked degree (Tata, 1968 ; Borthwick and Smellie, 1975). The significance of increased rRNA synthesis by oocytes of type $5 a$ follicles which are already very active is obscure. However, the nature of the growth response and the particular stage at which it occurs suggests that the oocyte has embarked on a specific sequence of differentiation.

Oocytes of the mouse ovary attain full size in follicles of the $5 a$ compartment (Pedersen and Peters, 1968). The next major developmental event involves a resumption of meiosis and maturation. However, during the intervening period of follicular development, RNA synthesis in the oocyte declines to a relatively low level. Although our results do not exclude a preovulatory burst of RNA synthesis, it seems likely that transcripts important for at least some of the events of nuclear or cytoplasmic maturation are produced by oocytes of the $5 a$ follicle. It is only after the attainment of full size that oocytes become competent to undergo nuclear maturation in vitro. Smaller oocyles are incompetent (Sorensen andWassarman, 1976). Recent biochemical evidence suggests that the pattern of proteins synthesized during meiosis may be governed by preformed molecules (Golbus and Stein 1976) which had been sequestered in the oocyte nucleus and released into the cytoplasm after rupture of the nuclear membrane (Schultz and Wassarman, 1977). Cytoplasmic maturation follows germinal vesicle breakdown in the rat and sperm penetration and fertilization become possible (Niwa and Chang, 1975).

\section{Conclusion.}

The major period of RNA production in the mammatian oocyte occurs during growth. Accumulation of the major RNA species appears to be co-ordinated with the activities of the transcription enzymes, the RNA polymerases. The pattern of polymerase I activity may be modified by exogenous gonadotrophin, specifically in large oocytes of multilaminar follicles. RNA's synthesized at this stage may have a role in the development of meiotic maturation competence.

EEC Seminar on « Ovarian stimulation and egg quality in mammals », Luynes, France, octobre 1978.

Acknowledgement. - This work was supported, in part, by a Queen Elizabeth II Fellowship ((G.P.M.M.) and by the Clive and Vera Ramaciotti Foundation (S.L-M.).

Résumé. Nous avons examiné les activités de transcription du génome de l'ovocyłe de souris pendant la croissance du follicule afin d'obtenir des informations sur les étapes auxquelles la synthèse d'ARN devient importante. La synthèse de l'ARN dans les ovocytes a été mesurée à différentes étapes de la croissance en utilisant une application cytochimique du dosage biochimique standard d'ARN polymérase ADN-dépendant. La présence de polymérases nucléolaires et nucléaires a été détectée par autoradiographie et leurs activités relatives quantifiées par comptage des grains. L'ensemble des activités, relativement faible dans les ovocytes du pool de petits follicules au repos, augmente lorsque la croissance débute, atteignant un pic lorsque les ovocytes approchent de la taille maximum. Ensuite, les activités ARN polymérases tombent rapidement pour devenir très basses dans les ovocytes des grands follicules à antrum. L'administration de PMSG à la souris n'a pas d'effet significatif 
sur la polymérase des ovocytes des petits follicules ou au cours des premières étapes de la croissance du follicule lorsqu'il est comparé aux témoins traités avec du sérum physiologique. Cependant, dans les ovocytes ayant atteint leur taille maximum, une augmentation statistiquement significative du marquage nucléolaire est détectée après traitement PMSG. Les niveaux élevés d'activité ARN polymérase sont limités aux ovocytes de ce compartiment de croissance. Ces observations sont discutées par rapport à la façon dont la production de transcripteurs de gènes est régulée au cours de la croissance de l'ovocyte, en tenant compte à la fois du stockage des molécules d'information et du développement de la maturation méiotique.

\section{References}

BACHVAROVA R., 1974. Incorporation of tritiated adenosine into mouse ovum RNA. Devel. Biol., 40, $52-58$.

BORTHWICK N. M., SMELLIE R. M. S., 1975. The effects of œstradiol-17 $\beta$ on the RNA polymerases of immature rabbit uterus. Biochem. J., 147, 91-101.

BROWN D. D., LITTNA E., 1964. RNA synthesis during development of Xenopus laevis the South African clawed toad. J. mol. Biol., 8, 669-687.

FLAX M. H., 1953. Ribose nucleic acid and protein during oogenesis and early embryonic development in the mouse. Ph. D. Thes. Columbia Univ.

GOLBUS M. S., STEIN M. P., 1976. Qualifative patterns of protein synthesis in the mouse oocyte. J. exp. Zool., 198, 337-342.

JAHN C. L., BARAN M. M., BACHVAROVA R., 1976. Stability of RNA synthesized by the mouse oocyte during its major growth phase. J. exp. Zool., 197, 161-172.

JOHNSON L. F., ABELSON H. T., GREEN H., PENMAN S., 1974. Changes in RNA in relation to growth of the fibroblast. I. Amount of mRNA, rRNA and tRNA in resting and growing cells. Cell, 1, 95-100.

JOHNSON L. F., ABELSON H. T., PENMAN S., GREEN H., 1977. The relative amounts of the cytoplasmic RNA species in normal, transformed and senescent cultured cell lines. J. Cell Physiol., $90,465-470$.

JOHNSON L. F., LEVIS R., ABELSON H. T., GREEN H., PENMAN S., 1976. Changes in RNA in relation to growth of the fibroblast. IV. Alterations in the production and processing of $m R N A$ and rRNA in resting and growing cells. J. Cell Biol., 71, 933-938.

MOORE G. P. M., 1978. RNA synthesis in fixed cells by endogenous RNA polymerases. Expt. Cell Res., 111, 317-326.

MOORE G. P. M., LINTERN-MOORE S., 1978. Transcription of the mouse oocyte genome, Biol. Reprod., 18, 865-871.

MOORE G. P. M., LINTERN-MOORE S., 1979. Endogenous RNA polymerase I activity is stimulated in the mouse oocyte after gonadotrophin treatment. Biol! Reprod. (in press).

MOORE G. P. M., LINTERN-MOORE S., PETERS H., FABER M., 1974. RNA synthesis in the mouse oocyte. J. Cell Biol., 60, 416-422.

MOORE G. P. M., RINGERTZ N. R., 1973. Localization of DNA-dependent RNA polymerase activities in fixed human fibroblasts by autoradiography. Expt. Cell Res., 76, 223-228.

NIWA K. CHANG M. C., 1975. Fertilization of rat eggs in vitro at various times before and after ovulation with special reference to fertilization of ovarian oocytes matured in culture. $J$. Reprod. Fert., 43, 435-451.

OAKBERG E. F., 1968. Relationship between stage of follicular development and RNA synthesis in the mouse oocyte. Mutation Res., 6, 155-165.

OLDS P. J., STERN S., BIGGERS J. D., 1973. Chemical estimates of the RNA and DNA contents of the early mouse embryo. J. exp. Zool., 186, 39-46.

PEDERSEN T., PETERS H., 1968. Proposal for a classification of oocytes and follicles in the mouse ovary. J. Reprod. Fert., 17, 555-557.

ROEDER R. G., RUTTER W. J., 1970. Specific nucleolar and nucleoplasmic RNA polymerases. Proc. nat. Acad. Sci. (USA), 65, 675-682. 
SCHULTZ R. M., WASSARMAN P. M., 1977. Specific changes in the pattern of protein synthesis during meiotic maturation of mammalian oocytes in vitro. Proc. nat. Acad. Sci. (USA), 74, 538 541.

SORENSEN R. A., WASSARMAN P. M., 1976. Relationship between growth and meiotic maturation of the mouse oocyte. Devl. Biol., 50, 531-536.

TATA J. R., 1968. Hormonal regulation of growth and protein synthesis. Nature (Lond), 219, $331-337$. WEINMANN, R., ROEDER R. G., 1974. Role of DNA-dependent RNA polymerase III in the transcription of the t-RNA and 5S RNA genes. Proc. nat. Acad. Sci. (USA), 71, 1790-1794.

ZYLBER, E. A., PENMAN S., 1971. Products of RNA polymerases in Hela cell nuclei. Proc. nat. Acad. Sci. (USA), 68, 2861-2865. 